\title{
HO CHI MINH'S EDUCATIONAL IDEOLOGY AND ITS MEANING IN EDUCATION INNOVATION IN VIETNAM TODAY
}

\section{LA IDEOLOGÍA EDUCATIVA DE HO CHI MINH Y SU SIGNIFICADO EN LA INNOVACIÓN DE LA EDUCACIÓN EN VIETNAM HOY}

Ngo Thi Cam-Lien ${ }^{1}$; Cao Xuan Long ${ }^{2}$.

1. Institute of Party History - Ho Chi Minh National Academy, Vietnam.ngothicamlien1986@gmail.com 2. University of Social Sciences and Humanities - VNU - HCM, Vietnam. caoxuanlong.khoatriet@gmail.com

\section{ABSTRACT}

Education is one of the important contents in Ho Chi Minh's ideology to contribute to solving the requirements of Vietnam's history and society in the early modern period. His educational ideology has been expressed quite abundantly and profoundly through issues such as: purposes, roles, content, methods, etc. in people education. That ideology has still brought out the breath of the era to this day, and has theoretical and practical significance, directing the process of educational development and innovation in Vietnam today.

Keywords: Ho Chi Minh; Ho Chi Minh ideology; education; History of the educational ideology of Vietnam.

Cómo citar:

Cam-Lien, Ngo Thi; Xuan Long, Cao. (2021). HO CHI MINH'S EDUCATIONAL IDEOLOGY AND ITS MEANING IN EDUCATION INNOVATION IN VIETNAM TODAY. Revista de Investigaciones Universidad del Quindio, 33(1), 214-220. https://doi.org/10.33975/riuq.vol33n1.560 


\section{RESUMEN}

La educación es uno de los contenidos importantes en la ideología de Ho Chi Minh para contribuir a resolver los requisitos de la historia y la sociedad de Vietnam en el período moderno temprano. Su ideología educativa se ha expresado de manera bastante abundante y profunda a través de cuestiones como propósitos, roles, contenidos, métodos, etc. en la educación de personas. Esa ideología todavía ha sacado el aliento de la era hasta el día de hoy, y tiene un significado teórico y práctico, dirigiendo el proceso de desarrollo e innovación educativos en Vietnam hoy.

Palabras clave: Ho Chi Minh; Ideología de Ho Chi Minh; educación; Historia de la ideología educativa de Vietnam.

\section{INTRODUCTION}

Ho Chi Minh (1890-1969) - is not only a representative thinker, revolutionary, writer, poet, patriot, etc., of the Vietnamese nation in the early modern period, but also internationally honored as a "hero of national liberation, world cultural celebrity". During his revolutionary life, he left humanity with many valuable thoughts. Especially, one of the important contents in that ideological system is education. Because through this thought, Ho Chi Minh pointed out a very important method to solve the requirements of Vietnam's historical - social reality at the end of the 19th century and the beginning of the 20th century, which was the liberation of nation, country, people; That thought was creatively inherited from the Vietnamese cultural tradition with the absorption of Eastern and Western philosophies in history, and was fundamentally transformed by the worldview and methodology of Marxism - Leninism; Through lively and rich revolutionary activities, Ho Chi Minh introduced a new practical and profound perspective on education and made it lively, practical, close to life, at the same time, have profound general meaning, the theory of comprehensive human education and training. The UNESCO Resolution assessed: "The important and many-sided contributions of President Ho Chi Minh to the fields of culture, education and the arts crystalizes the cultural tradition of the Vietnamese people which stretches back several thousand years and his ideals embody the aspirations of peoples in the affirmation of their cultural identity and the promotion of mutual understanding" (Many authors, 2002, p.5). That depth, comprehensiveness and specialty in the view of education are expressed by Ho Chi Minh through the following contents:

\section{PROBLEM SOLVING}

The first, regarding the purpose of education, Ho Chi Minh assumed that education had to pay attention to the constant goal of "Learning to work, to be a human, and to be an official. Learning to serve our union, the class and the people, our motherland and humanity" (Ho Chi Minh, 2000, vol. 5, p.1365). Therefore, education is not simply a cultural education, but also a practice of human skills and morality. The education must be towards "primarily teaching students to love the country and the people, teaching students to be independent, self-reliant, not to be inferior to anyone, not to be slaves" (Ho Chi Minh, 2000, volume 5, p.339).

Ho Chi Minh pointed out the prerequisite task that the new education needs to "train the students to be useful citizens for Vietnam, an education that fully develops the available capacities of the students." (Ho Chi Minh, 2000, vol. 4, p.32), helping people to be self-aware of their rights, values, and strength in order to liberate themselves, towards achieving national independence against 
colonialism to take ownership themselves, not to continue the bondage of backward feudal.

The second, for the object of education, according to Ho Chi Minh, educational activities do not care the class, age, education level, gender, everyone needs to be educated. In particular, he is interested in educating women because they are a very important and indispensable part of society, they are wives and mothers, who have a great influence on the formation of the initial personality of children, he wrote: "Women need to learn even more, women have been restrained for a long time, this is the time for women to try to keep up with men, to be worthy of being a member of our country, having rights of election and candidacy" (Ho Chi Minh, 2000, vol. 4, p.38-39).

The third, regarding the role of education, from the purpose of education, Ho Chi Minh affirmed that education played a very important role for each individual and every nation, every country. He said that: "Whether our Vietnam becomes beautiful or not, whether the Vietnamese nation can step up to the stage of glory to have equal role with the great powers in the world, your study largely contributes to this" (Ho Chi Minh, 2000, vol. 4, p.32-33). Therefore, Ho Chi Minh always affirmed that education was the first national policy, the first priority, even it was paid attention one step ahead compared to other development policies of Vietnam: "If a family is uneducated, it will take advantage of that family. A damaged person brings a little harm, two damaged persons bring double harm, sometimes it follows officials to find out about their institutions" (Ho Chi Minh, 2000, vol. 7, p.128). People are the center of all activities, so human education contributes to changing human perception and actions, which is also bringing the level of the whole society up and helping humanity to develop more and more.

Ho Chi Minh affirmed: "An ignorant nation is a weak one" (Ho Chi Minh, 2000, volume 4, p.8), therefore, education has a very important position in the building and developing country.
Recognizing that situation, President Ho Chi Minh paid great attention to education, he assumed that "killing the ignorance" is not less important than "killing foreign invaders", "Now we have gain independence. One of the works that must be done urgently at this time is to raise the people's intellectual level" (Ho Chi Minh, 2000, vol. 4, p.36).

\section{The fourth, regarding the content of human} education, Ho Chi Minh assumed that educational content must meet the requirements of comprehensive human development to have persons who possess both political integrity and professional competence, both talent and virtue. In which, political integrity includes morality, the love for the motherland, the determination to serve the people and country for all the life; professional competence includes the level of education, science, technology and military, etc. The dialectical relationship between political integrity and professional competence is the relationship between virtue and talent, with virtue being revolutionary morality. Ho Chi Minh once said:

"There are many comrades who either consider themselves to have a high cognitive level and full working experience - or do not have a progressive spirit, they play it by ear, so they refuse to study, they do not make selfcriticism to correct mistakes and make up for shortcomings." (Ho Chi Minh, 2000, vol. 4, p.26);

Therefore, officials must constantly improve both professional and ethical qualifications.

Ho Chi Minh always emphasized that "a person with talent but without virtue is useless, a person with virtue but without talent will meet difficulties in doing anything". That is not wrong, a talented person needs to have virtue and enthusiasm in the profession to be successful and be loved by many people. When a person does something with his enthusiasm, he does everything easier and feels his work more meaningful. Talented and virtuous 
people are loved by everyone everywhere, their work is more convenient, and they always seem to have the spirit of learning and improving their knowledge.

"All of you here will be officials. Therefore, it is necessary for you to remember the qualities that an official should have:

1) Not be proud, not be a "mandarin in revolution"

2) Be diligent: diligent in listening, diligent in observing, diligent in missioning, diligent in thinking, diligent in speaking, diligent in doing.

3) Always have progressive spirit, never stop studying, self-training, correcting shortcomings.

4) Be loyal to the revolutionary purpose: to keep the country independent and the people free" (Ho Chi Minh, 2000, vol. 4, p.34).

In addition, Ho Chi Minh also emphasized the education oflifestyle, he said that the establishment of people's cultured lives with civilized way of living, new way of life practice is based on the inheritance of national quintessence, therefore, he called on each class and individual in society to implement a new life, eliminate the remnants of old society He wrote:

"At this time, it is necessary for us to practice the new life of Laboriousness, Thriftiness, Honesty, Integrity.

The army must diligently practice and fight, the people increase production and work diligently, the resistance against foreign aggression will surely win. Therefore, we should implement the laboriousness.

Soldiers have to save ammunition with the motto of one bullet for one enemy. People have to save materials to help soldiers and evacuated people. Therefore, we should implement the thriftiness.

Everyone is chaste, not greedy, does not use public properties for private objectives, then everything will be done well. Therefore, everyone should implement honesty.

Every citizen must sacrifice his own interests for the sake of the country, enthusiastically support the resistance against foreign aggression, strive to increase production, eliminate those who betray the country and harm the people, to make our motherland unified and independent. That is Integrity. We can see that the new life is suitable to the times" (Ho Chi Minh, 2000, vol. 5, p.331).

In life, people have different lifestyles and ways of living. However, the difficult thing is how to live rightly. He wrote:

"Children must be obedient, at home, you must listen to your parents, at school, you must be diligent; with your friends, you must be respectful" (Ho Chi Minh, 2000, vol. 4, p.31).

In the coming school year, you should study hard, be obedient, obey your teachers, love your friends" (Ho Chi Minh, 2000, volume 4, p.32).

The fifth, in terms of education methods, Ho Chi Minh assumed that to educate people, it is necessary to combine many different methods to suit conditions, environment, and towards object to achieve educational goals. In the difficult situation of the country, he said:

"Those who are already literate should teach those who are not, you should contribute to the Vietnamese antiilliteracy campaign, as for six or seven years, you have started a movement to spread the national language and help the illiterate.

Those who are not literate should try your best to learn. If the wife is not literate, the husband will teach, if the younger brother is not literate, the older brother will teach, if the 
parents are not literate, the children will teach, if the servants are not literate, the owner will teach, the rich organize classes at their homes to teach the neighboring illiterate, the owners of hamlets, plantations, mines and factories open classes for their tenants and workers" (Ho Chi Minh, 2000, vol. 4, p.38-39).

Besides, He is very interested in two very important objects of teaching and learning activities, they are teachers and students. In particular, for teachers, besides imparting knowledge, they must always exchange knowledge and experiences with each other during the process of teaching and working and need to choose the appropriate communication method for each object. He wrote:

"Teachers have to find how to teach and what to teach, so that students can understand quickly, remember for a long time, and progress quickly" (Ho Chi Minh, 2000, volume 8, p.138). "Teach gradually from less to more, from easy to difficult, from low to high. Be not greedy to teach much, not indoctrinated. Teach in a practical way. Theory is closely linked to practice" (Ho Chi Minh, 2000, vol. 7, p.273);

For learners, it is necessary to work hard and be diligent in studying, Ho Chi Minh wrote:

"1. Must study diligently,

2. Must keep clean,

3. Must be disciplined,

4. Must follow the new life,

5. Must love and help our parents and siblings"

(Ho Chi Minh, 2000, vol. 4, p.851)

Must study hard and try to do 5 things: ARDENCY, SATISFACTION, PHILANTHROPY, SOLIDARITY, DISCIPLINE" (Ho Chi Minh, 2000, volume 4, p.886).

In addition, Ho Chi Minh also pointed out the very important role of the educational environment, he stated the relationship between education in school and education at home. Both the family and the school must have a close relationship with each other in the education of their children. Thereby creating a healthy, democratic and civilized educational environment, creating the most favorable conditions for education and learning. He wrote:

"In the school, there should have democracy. For all issues, teachers and students discuss together, anyone who has opinions should honestly express them. For unclear issue, it should be asked and discussed for clarity. However, democracy means that students must respect teachers, teachers must respect students, not "dogs of the same street bark alike". At the same time, teachers and students need to help servers in school. The staff should compete for healthy and delicious meals so that the students can eat well and study well.

School should keep close contact with the student's family, because education in school is only a part, there is also a need for education in society and in the family to make education in school better. Although education in school is good, without education in the family and in society, the results are not complete" (Ho Chi Minh, 2000, vol. 8, p.395).

Besides studying, it is also necessary to organize entertainment activities to rest and relax after stressful studying hours.

"Schools, families and youth organizations must closely connect in the education of young people. Young people must focus on studying and working, and also need time for entertainment." (Ho Chi Minh, 2000, vol. 7, p.456).

\section{CONCLUSION}

The meaning of Ho Chi Minh's ideology on education and training of Vietnamese people today, Ho Chi Minh's ideology on education and training is always revolutionary, scientific, simple, practical and lively. Therefore, the 
application of Ho Chi Minh's ideology to the current educational situation in our country has a great theoretical and practical significance in the cause of educational innovation and development.

The first practical and profound meaning in Ho Chi Minh's ideology on building new people is the viewpoint and purpose of human building. That purpose, according to Ho Chi Minh, is to train people to serve the country, class and nation. Those are comprehensive people who are both "political integrity" and "professional competence". In the current conditions, building new people is an urgent issue. Therefore, the Communist Party of Vietnam affirmed that human resources are the basic factor of rapid and sustainable development in the process of industrialization and modernization of the country. In the process of industrialization and modernization, it is necessary to have human resources that are sufficient in quantity, strong in quality. They are personnel with sufficient knowledge and having the ability to use advanced science and technology of the times; understanding social sciences and humanities, grasping the context of the times to constantly progress, having good health and loving labor, studying diligently to get advance, so it is necessary to "Build Vietnamese people to develop comprehensively, with good health, capacity and qualifications, and having a high responsibility for themselves, their families, society and the motherland. We should promote the development of human resources, especially high-quality human resources, to meet the requirements of the Fourth Industrial Revolution and international integration" (Document XIII, 2021, volume 1; p.231).

This is an issue that Ho Chi Minh is very interested in. Ho Chi Minh called on everyone in society to study and strive constantly. Especially, officials must be a model in everything and truly be "the faithful servant of the people". To have such officials following that principle, according to him, there is no other way than education. Human education is a factor contributing to social development.
Thus, the lesson, which has the most profound theoretical and practical significance in Ho Chi Minh's ideology on education today, is the point of view of determining human training strategies. According to Ho Chi Minh, it was reflected in the purpose and content of training and education that was outlined by him. Therefore, the strategy and objective of the current education of our country are, on the one hand, to raise the people's intellectual level, and on the other hand, to foster talents and train people, who are chaste, have the capacity for creative thinking, master the knowledge and modern science and technology, have good health, aesthetics and profession, have loyalty to the idea of national independence and socialism to become a mainstay of our societal system; They are comprehensive people, both "political integrity" and "professional competence", they know how to preserve and promote national cultural values, and at the same time, have the ability to absorb the cultural quintessence of humanity as Uncle Ho once pointed out.

In order to effectively implement the strategy of education and training of new people with comprehensive development, we need a scientific education method. Therefore, our Party has stated:

It is necessary to "renovate educational thought in a consistent manner, from program objectives, content of methods to organizational structure and system, and management mechanism to create a fundamental and comprehensive change of education of our country, approaching the regional and world level, overcoming patchwork innovation which lacks of overall vision and synchronous plan. We should strive to build a modern education, of the people, by the people and for the people, ensuring equality of learning opportunities for everyone, creating conditions for the society to learn and learn all the life, and meeting the requirements of industrialization and modernization of the country" (Communist Party of Vietnam, 2006, p.206). 
Therefore, the second valuable theoretical and practical lesson of Ho Chi Minh's educational ideology for the development of education in our country today is the application of human education methods outlined by Ho Chi Minh. His education methods are traditional, modern, systematic, specific, vivid, practical, revolutionary and scientific, close, imbued with Eastern philosophy of action, so they are always associated with life, bringing the breath of life and modernity. In particular, there are education methods such as dialogue between teachers and students, learner-centered approach, linking Vietnamese education through the revolutionary periods. They are also lessons and practical educational experiences, which are very specific, vivid, realistic and effective for each person directly working the education activities in particular and the education sector in general.
In summary, Ho Chi Minh's human education ideology is a valuable legacy, which has profound theoretical and practical significance throughout the Vietnamese revolution, it has lighted the way for the struggle to achieve victory. It is the great spiritual property of our Party and people. Under the leadership of the Communist Party of Vietnam, founded and trained by President Ho Chi Minh, the Vietnamese people stood up for independence, freedom, national reunification, and we have built the education and training, and have developed people of the new society - socialism. In the training of human resources and building new people for the industrialization of our country today, we should implement the goal of "rich people, strong country, fair and civilized society", that ideology of Ho Chi Minh has increasingly practical meaning.

\section{REFERENCE}

1. Communist Party of Vietnam. (2006). Document of the 10th National Party Congress, Hanoi, National Political Publishing House.

2. Communist Party of Vietnam. (2021). Document of the 13th National Party Congress, Volume 1, Hanoi, National Political Publishing House.

3. Many authors. (2002). Ho Chi Minh ideology-national cultural heritage, Hanoi, People's Army Publishing House.

4. Ho Chi Minh. (2000).Complete works, volume 1, Hanoi, National Political Publishing House.

5. Ho Chi Minh. (2000). Complete works, volume 4, Hanoi, National Political Publishing House.

6. Ho Chi Minh. (2000). Complete works, volume 5, Hanoi, National Political Publishing House.

7. Ho Chi Minh. (2000). Complete works, volume 7, Hanoi, National Political Publishing House.

8. Ho Chi Minh. (2000). Complete works, volume 8, Hanoi, National Political Publishing House.

9. The article is the research result from the Category C Project - 2022 of the National University Viet Nam - Ho Chi Minh City: "Ho Chi Minh's philosophical thought ..." chaired by Assoc.Prof. PhD Cao Xuan Long. 